\title{
Employees' Satisfaction of Government and Non-Government Banks in Tangail City, Bangladesh
}

\author{
Sayed Mohibul Hossen ", Ridwana Chowdhury \\ Department of Statistics, Faculty of Science, Mawlana Bhashani Science and Technology University, Tangail, Bangladesh
}

Email address:

m300cht@gmail.com (S. M. Hossen)

${ }^{*}$ Corresponding author

\section{To cite this article:}

Sayed Mohibul Hossen, Ridwana Chowdhury. Employees' Satisfaction of Government and Non -Government Banks in Tangail City, Bangladesh. Journal of Investment and Management. Vol. 7, No. 2, 2018, pp. 53-58. doi: 10.11648/j.jim.20180702.12

Received: February 13, 2018; Accepted: April 8, 2018; Published: May 8, 2018

\begin{abstract}
Employees' satisfaction is directly related to their dedication and performance, and customers' satisfaction. Satisfied employees' put their best effort into building and maintaining successful relationship between the bank and its customers. The present study attempts to identify the key facets contributing to employees' satisfaction in banks and to make a comparative analysis of employees' satisfaction in different ownership structures such as government banks and nongovernment banks of a small town in Bangladesh. Primary data was used in the study and the sample size of the study was 102 employees from these two sectors of banks situated in Tangail city. Factors including salary of employees, performance appraisal system, promotional strategies, employee's relationship with management and other co- employees, training and development program, influence of higher authority and working hours are found important for improving job satisfaction of bank employees in Tangail. By the analysis we have found that association between employees' job satisfaction and their Opportunity to take part in training, courses \& workshops, involvement in decision making, company's behavior as well as company's well treatment and opinion on Career appointments are significant. Increase in level of these factors improves overall satisfaction of employees which is identified by using statistical techniques.
\end{abstract}

Keywords: Employees' Satisfaction, Government, Non-Government, Banks

\section{Introduction}

Human life has become very complex and completed in now-a-days. In modern society the needs and requirements of the people are ever increasing and ever changing. When the people are ever increasing and ever changing and the people needs are not fulfilled they become dissatisfied. Dissatisfied people are likely to contribute very little for any purpose. Job satisfaction is one of the most popular and widely researched topics in the field of organizational psychology [9]. Locke [6] defines job satisfaction as a pleasurable or positive emotional state resulting from the appraisal of one's job or job experiences. Job satisfaction has been studied both as a consequence of many individual and work environment characteristics and as an antecedent to many outcomes. Employees who have higher job satisfaction are usually less absent, less likely to leave, more productive, more likely to display organizational commitment, and more likely to be satisfied with their lives [5]. Job satisfaction of industrial workers is very important for the industry to function successfully. Apart from managerial and technical aspects, employers can be considered as backbone of any industrial development. To utilize their contribution they should be provided with good working conditions to boost their job satisfaction. Researchers reported that a number of different factors can influence employee satisfaction with their workspaces, including building design, air quality and temperature, noise and lighting, ability of employees to personalize their workspaces and workspace design and management etc. It is generally understood that unfavorable conditions of office environment can have negative influences on employees' satisfaction, cause health problems and increase short-term sick leave.

Banking industry in Bangladesh started its journey -with nine banks including nationalized commercial banks, stateowned specialized banks and foreign banks. This financial service industry achieved major expansion in 1980's with the 
entrance of private banks. Now, fifty one banks with different ownership structures are operating in Bangladesh of which forty seven are scheduled and four are non-scheduled banks. At present, banking industry is facing aggressive competition and the level of competition is soaring day by day. To survive and grow in this competitive environment, banks are placing more emphasis on delivering desired satisfaction to their customers. Employees of the banks are the key service providers and their services are the Employees* satisfaction is also directly related to their performance, absenteeism, commitment, turnover and citizenship behavior in the bank which have a direct influence on the performance of a bank. Furthermore, it is evident that employees' satisfaction has a direct influence on customers* satisfaction. Job satisfaction indicates the feelings an employee has towards his or her job based on the evaluation of its characteristics [7]. The term employee satisfaction is used to describe whether employees are happy and contented, and fulfilling their desires and needs at work. Employee satisfaction is the satisfaction of employees with their jobs or the degree to which employees like their jobs [9]. So, employees' satisfaction has become a major concern to the banks for their survival and growth. Thus, an effort has been undertaken to measure level of satisfaction of employees working in different banks in Bangladesh and make a comparative analysis of their satisfaction with different ownership structure i.e., government and non-government banks of small town in Bangladesh [7].

We choose 11 banks at random from all the banks situated in Tangail city. We choose 5 government banks such as Sonali Bank, Rupali Bank, Janata Bank, Agrani Bank and Krishi Bank and 6 non-government banks such as Brac Bank, Dhaka Bank, Exim Bank, MTB, SIB and Prime Bank for our study. From these banks we get information from 102 employees about their job satisfaction.

Objective of the study i. To identity the key facts contributing to job satisfaction of the employees in government and non-government banks of Bangladesh.

ii. To make a comparative analysis on employees' satisfaction among government and non-government banks in Bangladesh.

iii. To identify the factors that affects the satisfaction level of the bank employees and to resolve them as possible.

\section{Materials and Methods}

Many studies have been carried out for big cities on employees satisfaction but for small towns the study is rare. So, we concentrate on that part. The study includes more than 102 samples from government and non-government banks in the small town of Tangail district in Bangladesh for both employees of the government and non-government banks. In the $1^{\text {st }}$ stage the well reputed bank branches were selected for study. 5 branches of government banks (Sonali Bank, Rupali Bank, Janata Bank, Agricultural Bank, Agrani Bank) and 5 branches of non-government banks (Dhaka Bank, Exim Bank, MTB, Shahjalal Islami Bank, Prime Bank, BRAC Bank) were selected at the second stage. In the third stage employees working in these 11 branches were personally approached through a structured questionnaire and primary data is collected. Primary data is collected from 11 AGMs and 92 employees working in selected 11 banks.

The study is conducted by using Simple Random Sampling technique where we consider the employees of government \& non-government banks in Tangail city. A survey method was used for the study and the data were collected by a Demographic Information Questionnaire and satisfaction Attitudes Scale. The questionnaire includes personal information, Work \& Work environment, Supervisor and Supervision, Rewards and Promotion, Participation and other things related with their satisfaction.

\section{Results and Discussion}

Table 1. Cross tabulation for finding the association between employees satisfaction of job with their working hour.

\begin{tabular}{|c|c|c|c|c|c|c|c|c|c|}
\hline & & \multicolumn{4}{|c|}{ Non- Government bank } & \multicolumn{4}{|c|}{ Government bank } \\
\hline & & \multicolumn{3}{|c|}{ Working hours } & \multirow{2}{*}{ Total } & \multicolumn{3}{|c|}{ Working hours } & \multirow{2}{*}{ Total } \\
\hline & & No & Neutral & Yes & & No & Neutral & Yes & \\
\hline \multirow{2}{*}{ Satisfaction of Job } & No & 8 & 2 & 9 & 19 & 10 & 5 & 14 & 29 \\
\hline & Yes & 14 & 4 & 7 & 25 & 8 & 4 & 17 & 29 \\
\hline Total & & 22 & 6 & 16 & 44 & 18 & 9 & 31 & 58 \\
\hline
\end{tabular}

Hypothesis

$\mathrm{H}_{0}$ : There is no association between employees' satisfaction with their job and their working hour.

$\mathrm{H}_{1}$ : There is association between employees' satisfaction with their job and their working hour.

Table 2. Chi-square table for finding the association between employees satisfaction of job with their working hour.

\begin{tabular}{lllll}
\hline & Bank type & Value & D. F. & P-Value \\
\hline \multirow{2}{*}{ Pearson chi-square } & Government & .624 & 2 & .732 \\
& Non-Government & 1.768 & 2 & .413 \\
\hline
\end{tabular}

Comment: From the above table we can see that, employee's satisfaction and their working hour is highly insignificant. So, we may not reject the null hypothesis. That is, there is no association between employees' job satisfaction and their working hour. 
Table 3. Cross tabulation for finding the association between employees' satisfaction of job with their opportunity to taking part in training, courses \& workshops.

\begin{tabular}{|c|c|c|c|c|c|c|c|c|c|}
\hline \multicolumn{6}{|c|}{ Non- Government bank } & \multicolumn{4}{|c|}{ Government bank } \\
\hline & & \multicolumn{3}{|c|}{$\begin{array}{l}\text { Opportunity to take part in training, courses \& } \\
\text { workshops }\end{array}$} & \multirow[t]{2}{*}{ Total } & \multicolumn{3}{|c|}{$\begin{array}{l}\text { Opportunity to take part in training, courses \& } \\
\text { workshops }\end{array}$} & \multirow[t]{2}{*}{ Total } \\
\hline & & No & Neutral & Yes & & No & Neutral & Yes & \\
\hline \multirow{3}{*}{$\begin{array}{l}\text { Satisfaction of Job } \\
\text { Total }\end{array}$} & No & 5 & 7 & 7 & 19 & 7 & 7 & 15 & 29 \\
\hline & Yes & 1 & 5 & 19 & 25 & 4 & 5 & 20 & 29 \\
\hline & & 6 & 12 & 26 & 44 & 11 & 12 & 35 & 58 \\
\hline
\end{tabular}

Hypothesis

$\mathrm{H}_{0}$ : There is no association between employees' job satisfaction with their opportunity to take part in training, courses \& workshops

$\mathrm{H}_{1}$ : There is association between employees' satisfaction with their job and their opportunity to take part in training, courses \& workshop

Table 4. Chi-square table for finding the association between employees' satisfaction of job with their opportunity to taking part in training, courses \& workshops.

\begin{tabular}{lllll}
\hline & Bank type & Value & D. F. & P-Value \\
\hline \multirow{2}{*}{ Pearson chi-square } & Government & 1.866 & 2 & .393 \\
& Non-Government & 7.867 & 2 & .020 \\
\hline
\end{tabular}

Comment:

Here we observe that, employees' satisfaction and their duration of job is highly significant. So, we may reject the null hypothesis. That is, there is high association between employees' job satisfaction and their Opportunity to take part in training, courses \& workshops.

Table 5. Cross tabulation for finding the association between employees' satisfaction of job with their salary provided by the company.

\begin{tabular}{|c|c|c|c|c|c|c|c|c|c|}
\hline \multicolumn{6}{|c|}{ Non- Government bank } & \multicolumn{4}{|c|}{ Government bank } \\
\hline & & \multicolumn{3}{|c|}{ Good Salary } & \multirow{2}{*}{ Total } & \multicolumn{3}{|l|}{ Good Salary } & \multirow{2}{*}{ Total } \\
\hline & & No & Neutral & Yes & & No & Neutral & Yes & \\
\hline \multirow{2}{*}{ Satisfaction of Job } & No & 5 & 4 & 10 & 19 & 7 & 3 & 19 & 29 \\
\hline & Yes & 4 & 6 & 15 & 25 & 3 & 1 & 25 & 29 \\
\hline Total & & 9 & 10 & 25 & 44 & 10 & 4 & 44 & 58 \\
\hline
\end{tabular}

Hypothesis

$\mathrm{H}_{0}$ : There is no association between employees' satisfaction with their job and their salary provided by the company.

$\mathrm{H}_{1}$ : There is association between employees' satisfaction with their job and their salary provided by the company.

Table 6. Chi-square table for finding the association between employees' satisfaction of job with their salary provided by the company.

\begin{tabular}{lllll}
\hline & Bank type & Value & D. F. & P-Value \\
\hline \multirow{2}{*}{ Pearson chi-square } & Government & $3.418^{\text {a }}$ & 2 & .181 \\
& Non-Government & $.706^{\text {a }}$ & 2 & .703 \\
\hline
\end{tabular}

Comment:

Here we observe that, employees' satisfaction and their opinions about good salary provided by the company is significant. So, we may reject the null hypothesis. That is, there is high association between employees' job satisfaction and their opinions about good salary provided by the company.

Table 7. Cross tabulation for finding the association between employees 'satisfaction of job and their involvement in decision making.

\begin{tabular}{|c|c|c|c|c|c|c|c|c|c|}
\hline \multicolumn{6}{|c|}{ Non- Government bank } & \multicolumn{4}{|c|}{ Government bank } \\
\hline & & \multicolumn{3}{|c|}{ Involvement in decision making. } & \multirow{2}{*}{ Total } & \multicolumn{3}{|c|}{ Involvement in decision making. } & \multirow{2}{*}{ Total } \\
\hline & & No & Neutral & Yes & & No & Neutral & Yes & \\
\hline \multirow{2}{*}{ Satisfaction of Job } & No & 5 & 6 & 8 & 19 & 6 & 6 & 17 & 29 \\
\hline & Yes & 4 & 12 & 9 & 25 & 4 & 6 & 19 & 29 \\
\hline Total & & 9 & 18 & 17 & 44 & 10 & 12 & 36 & 58 \\
\hline
\end{tabular}

Hypothesis

$\mathrm{H}_{0}$ : There is no association between employees' satisfaction with their job and their involvement in decision making.

$\mathrm{H}_{1}$ : There is association between employees' satisfaction with their job and their involvement in decision making. 
Table 8. Chi-square table for finding the association between employees 'satisfaction of job and their involvement in decision making.

\begin{tabular}{lllll}
\hline & Bank type & Value & D. F. & P-Value \\
\hline \multirow{2}{*}{ Pearson chi-square } & Government & $.511^{\mathrm{a}}$ & 2 & .774 \\
& Non-Government & 1.377 & 2 & .502 \\
\hline
\end{tabular}

Comment:

From the above table we can see that, employees' satisfaction and their involvement in decision making significant. So, we may reject the null hypothesis. That is, there is some association between employees' job satisfaction and their involvement in decision making..

Table 9. Cross tabulation for finding the association between employees satisfaction of job with incensement of their responsibility if they perform well.

\begin{tabular}{|c|c|c|c|c|c|c|c|c|c|}
\hline \multicolumn{6}{|c|}{ Non- Government bank } & \multicolumn{4}{|c|}{ Government bank } \\
\hline & & \multicolumn{3}{|c|}{$\begin{array}{l}\text { Employees increasing responsibility by their well } \\
\text { performance. }\end{array}$} & \multirow[t]{2}{*}{ Total } & \multicolumn{3}{|c|}{$\begin{array}{l}\text { Employees increasing responsibility by their } \\
\text { well performance. }\end{array}$} & \multirow[t]{2}{*}{ Total } \\
\hline & & No & Neutral & Yes & & No & Neutral & Yes & \\
\hline \multirow{2}{*}{ Satisfaction of Job } & No & 0 & 2 & 17 & 19 & 0 & 4 & 25 & 29 \\
\hline & Yes & 0 & 3 & 22 & 25 & 0 & 7 & 22 & 29 \\
\hline Total & & 0 & 5 & 39 & 44 & 0 & 11 & 47 & 58 \\
\hline
\end{tabular}

\section{Hypothesis}

$\mathrm{H}_{0}$ : There is no association between employees' satisfaction with their job and their increasing responsibility if they perform well.

$\mathrm{H}_{1}$ : There is association between employees' satisfaction with their job and their increasing responsibility if they perform well.

Table 10. Chi-square table for finding the association between employees satisfaction of job with incensement of their responsibility if they perform well.

\begin{tabular}{lllll}
\hline & Bank type & Value & D. F. & \\
\hline \multirow{2}{*}{ Pearson chi-square } & Government & $1.010^{\mathrm{a}}$ & 1 & .315 \\
& Non-Government & .023 & 1 & .879 \\
\hline
\end{tabular}

Comment:

From the above hypothesis table, we observe that both of the values are significant. So, we may reject the null hypothesis. That is, there is an association between employees' job satisfaction and their company's behavior as well as company's well treatment.

Table 11. Cross tabulation for finding the association between employees' satisfaction of job with incensement of their Companies well treatment of both government and non-government bank.

\begin{tabular}{|c|c|c|c|c|c|c|c|c|c|}
\hline \multicolumn{6}{|c|}{ Non-Government bank } & \multicolumn{4}{|c|}{ Government bank } \\
\hline & & \multicolumn{3}{|c|}{ Company treats well } & \multirow{2}{*}{ Total } & \multicolumn{3}{|c|}{ Company treats well } & \multirow{2}{*}{ Total } \\
\hline & & No & Neutral & Yes & & No & Neutral & Yes & \\
\hline \multirow{2}{*}{ Satisfaction of Job } & No & 7 & 3 & 9 & 19 & 10 & 5 & 14 & 29 \\
\hline & Yes & 5 & 6 & 14 & 25 & 5 & 9 & 15 & 29 \\
\hline Total & & 12 & 9 & 23 & 44 & 15 & 14 & 29 & 58 \\
\hline
\end{tabular}

Hypothesis

$\mathrm{H}_{0}$ : There is no association between employees' satisfaction with their job and the company's behavior.

$\mathrm{H}_{1}$ : There is association between employees' satisfaction with their job and the company's behavior.

Table 12. Chi-square table for finding the association between employees' satisfaction of job with incensement of their Companies well treatment of both government and non-government bank.

\begin{tabular}{lllll}
\hline & Bank type & Value & D. F. & P-Value \\
\hline \multirow{2}{*}{ Pearson chi-square } & Government & 2.844 & 2 & 0.241 \\
& Non-Government & $1.632 \mathrm{a}$ & 2 & .442 \\
\hline
\end{tabular}

Comment:

From the above hypothesis table, we can see that, both of the values are significant. So, we may reject the null hypothesis. That is, there is an association between employees' job satisfaction and their company's behavior as well as company's well treatment. 
Table 13. Cross tabulation for finding the association between employee's satisfactions of job with incensement of their opinion on Career appointments.

\begin{tabular}{|c|c|c|c|c|c|c|c|c|c|}
\hline \multirow[t]{3}{*}{ Government bank } & & & & & \multicolumn{4}{|c|}{ Non- Government bank } & \multirow{3}{*}{ Total } \\
\hline & & \multicolumn{3}{|c|}{ Career appointments are well respected } & \multirow{2}{*}{ Total } & \multicolumn{3}{|c|}{ Career appointments are well respected } & \\
\hline & & No & Neutral & Yes & & No & Neutral & Yes & \\
\hline \multirow{2}{*}{ Satisfaction of Job } & No & 6 & 5 & 8 & 19 & 7 & 5 & 17 & 29 \\
\hline & Yes & 4 & 6 & 15 & 25 & 5 & 5 & 19 & 29 \\
\hline Total & & 10 & 11 & 23 & 44 & 12 & 10 & 36 & 58 \\
\hline
\end{tabular}

Hypothesis

$\mathrm{H}_{0}$ : There is no association between employees satisfaction with their opinion on Career appointments.

$\mathrm{H}_{1}$ : There is association between employees satisfaction with their opinion on Career appointments.

Table 14. Chi-square table for finding the association between employee's satisfactions of job with incensement of their opinion on Career appointments.

\begin{tabular}{lllll}
\hline & Bank type & Value & D. F. & P-Value \\
\hline \multirow{2}{*}{ Pearson chi-square } & Government & $.444^{\mathrm{a}}$ & 2 & .801 \\
& Non-Government & $1.837^{\mathrm{a}}$ & 2 & .399 \\
\hline
\end{tabular}

Comment:

From the above hypothesis table, we can see that, both of the values of career appointments are significant. So, we may reject the null hypothesis. That is, there is an association between employees' job satisfaction and their opinion on Career appointments.

Table 15. Cross tabulation for finding the association between employee's satisfactions of job with incensement of their opinion on Encouragement and support for future development plans.

\begin{tabular}{|c|c|c|c|c|c|c|c|c|c|}
\hline \multicolumn{6}{|l|}{ Government bank } & \multicolumn{4}{|c|}{ Non-Government bank } \\
\hline & & \multicolumn{3}{|c|}{$\begin{array}{l}\text { Encouragement and support for future } \\
\text { development plans. }\end{array}$} & \multirow[t]{2}{*}{ Total } & \multicolumn{3}{|c|}{$\begin{array}{l}\text { Encouragement and support for future development } \\
\text { plans. }\end{array}$} & \multirow[t]{2}{*}{ Total } \\
\hline & & No & Neutral & Yes & & No & Neutral & Yes & \\
\hline \multirow{2}{*}{ Satisfaction of Job } & No & 6 & 9 & 4 & 19 & 8 & 9 & 12 & 29 \\
\hline & Yes & 1 & 4 & 20 & 25 & 4 & 4 & 21 & 29 \\
\hline Total & & 7 & 13 & 24 & 44 & 12 & 13 & 33 & 58 \\
\hline
\end{tabular}

Hypothesis

$\mathrm{H}_{0}$ : There is no association between employees' satisfaction with their opinion on encouragement and support for future development plans.

$\mathrm{H}_{1}$ : There is association between employees' satisfaction with their opinion on encouragement and support for future development plans

Table 16. Chi-square table finding the association between employee's satisfactions of job with incensement of their opinion on Encouragement and support for future development plans.

\begin{tabular}{lllll}
\hline & Bank type & Value & D. F. & P-Value \\
\hline \multirow{2}{*}{ Pearson chi-square } & Government & $5.711^{\mathrm{a}}$ & 2 & .058 \\
& Non-Government & $15.634^{\mathrm{a}}$ & 2 & .000 \\
\hline
\end{tabular}

Comment:

From the above hypothesis table, we can see that, both of the values of career appointments are significant. So, we may reject the null hypothesis. That is, there is an association between employees' job satisfaction and their opinion on Encouragement and support for future development plans.

\section{Conclusion}

Every organization depends on their manpower for success and development. In-fact, if workers or employees work properly, the organization can easily achieve the target. To get the best out of the employees in work proper attention must be given to enhance their job satisfaction level. While studying the job satisfaction level of employees of different government and non-government banks, the finding is that on average they were satisfied with their jobs. Although some weaknesses exist in contents of Welfare facilities, other facilities, performance Appraisal system, behavior of organization, Career Development System and Promotion system, the bank can easily overcome them through improvement measures.

This study mainly investigated organizations the relationship between workers and certain factors such as working conditions, training development facilities and long working hours. Employee's welfare measures and Job security should be given utmost importance, so that the employee's turnover may be restricted. If these factors are given little more care, the company can maintain good workers with high level of satisfaction, organizational commitment and involvement. This will in turn lead to effectiveness and efficiency in their work which leads to 
increased productivity. Researcher concluded that overall the job satisfaction of bank officers though is not very high but still satisfactory. But there is still considerable room for improvements. An organization should try to take every possible step to enhance job satisfaction among employees because if employees are satisfied then customers associated with it will also be satisfied.

\section{Suggestions}

1. Training and development programmers must be provided to the employees at regular intervals to update their knowledge and skills.

2. Salaries to the employees must be given in accordance to their experience in the job.

3. The kind of work given to an employee should be according to his/her abilities and knowledge and their efforts for doing a particular task must be valued by giving appreciations and rewards to the employees for their hard work so that their level of motivation increases.

4. The bank should provide certain benefits to their employees, so that they can perform well to achieve organizational goals.

5. The job should be interesting enough, so that it must create enthusiasm among the employees.

6. Enough freedom must be given to the employees to take important decisions. Workers participation in management should be increase

\section{References}

[1] K. Bhatti, T. Qureshi, "Impact of employee participation on job satisfaction, employee commitment and employee productivity," International Review of Business Research Papers, 2007, 3 (2), 54-68.

[2] S. Chandan, Jit, "Organizational behavior," New Delhi Vikas Publishing House pvt. Ltd. 2005, 3rd edition. pp. 83-85. 3622.
[3] K. H. CH, "Internal Service Quality-An Empirical Assessment," International journal of quality management, 1999.

[4] H. T. Khshab, "The impact of some measures to marketing performance of employees in banks," Mosel University, 2005.

[5] S. H. Lease, "Work attitudes and outcomes," Journal of Vocational Behavior, 1998, vol. 53 (2): 154-183.

[6] E. Locke, "The nature and causes of job satisfaction," In M. D. Dunnette (Ed.), Handbook of industrial and organizational psychology, 1976 pp. 1297-1349). Chicago: Rand McNally.

[7] M. M. Iqbal, "Job Satisfaction in Commercial Banks of Bangladesh with Different Ownership Structures: A Comparative Study," 2013.

[8] M. Shallu, Sehgal, "Job satisfaction of bank employees" International Journal of Marketing, Financial Services \& Management Research,” vol. 1 Issue 7, ISSN 2277, July 2012.

[9] P. E. Spector, "Job Satisfaction: Application, Assessment, Causes, and Consequences. Thousand Oaks, CA: Sage," 1997.

[10] http://research.daffodilvarsity.edu.bd/wpcontent/uploads/2014/04/Eastern-University-JournalDecember-2006.pdf.

[11] Anamika, "Stress and Job Satisfaction level among Government and Private Sector Bank Employees: a Study on Urban Area in Patna India," The International Journal of Indian Psychology, Vol. 4, Issue 1, October-December 2016.

[12] Weerasinghe, "Factors Affecting to Job Satisfaction of Banking Employees in Sri Lanka," Business and Management Horizons, Vol. 5, No. 1, 2017.

[13] G. Kumari and K. M. Pandey, "Job Satisfaction in Public Sector and Private Sector: A Comparison," International Journal of Innovation, Management and Technology, Vol. 2, No. 3, June 2011.

[14] N. I. Sarker, A. Sultana, S. Prodhan, "Job satisfaction of employees of public and private organizations in Bangladesh," Journal of Political Science, Public and International Affairs Vol. 1 (1), pp. 002-008, June, 2017. 